\title{
Water Uptake of Thermally Modified Norway Spruce
}

\section{Upijanje vode toplinski modificirane norveške smreke}

\author{
Original scientific paper • Izvorni znanstveni rad \\ Received-prispjelo: 30. 6. 2014. \\ Accepted-prihvaćeno: 6. 11. 2015. \\ UDK: 674.032.13; 630*812.4; 630*812.22 \\ doi:10.5552/drind.2015.1421
}

\begin{abstract}
Thermal modification of wood has been commercially available for almost twenty years but the complete mechanism of improved durability is still not completely understood. It is known that the temperature and duration of the modification influences the properties of the final products. There are several potential reasons for the increased durability of the modified wood. In recent research in particular, water exclusion efficiency has been identified as one of the key mechanisms. In order to elucidate this presumption, specimens made of Norway spruce heartwood were thermally modified at 6 different temperatures $\left(160{ }^{\circ} \mathrm{C}, 180{ }^{\circ} \mathrm{C}, 190{ }^{\circ} \mathrm{C}, 200{ }^{\circ} \mathrm{C}, 210^{\circ} \mathrm{C}\right.$ and $230^{\circ} \mathrm{C}$ ) for three hours according to the Silvapro ${ }^{\circledR}$ procedure. Control specimens were left unmodified. Three sets of tests were performed: (a) samples were soaked in water for 4 days and then positioned on load cells and allowed to dry until a constant mass was achieved; (b) short term water uptake was determined with a tensiometer and (c) wood-water interactions were verified using constant gravimetric moisture measurement during outdoor exposure. As expected, the degree of modification was reflected in the moisture content of the wood during testing. Short and medium term water uptakes correlated quite well with the performance of wood in outdoor applications. On the other hand, long term tensiometer measurements were not in line with either short term water uptake or outdoor measurements.
\end{abstract}

Key words: load cell, Picea abies, tensiometer, thermal modification, water uptake, field testing

SAŽETAK - Toplinski modificirani drvo dostupno je na tržištu već gotovo dvadeset godina međutim, potpuni mehanizam poboljšane trajnosti drva još uvijek nije sasvim razjašnjen. Poznato je da temperatura i trajanje modifikacije utječu na svojstva konačnog proizvoda. Nekoliko je razloga za povećanje trajnosti toplinski modificiranog drva. U recentnim istraživanjima učinkovito je odstranjenje vode identificirano kao jedan od ključnih mehanizama za poboljšanje trajnosti drva. Kako bi se razjasnila ta pretpostavka, uzorci drva srži norveške smreke toplinski su modificirani pri šest različitih temperatura (160, 180, 190, 200, 210 i $\left.230^{\circ} \mathrm{C}\right)$ tijekom tri sata prema postupku Silvapro ${ }^{\circledR}$. Kontrolni su uzorci ostali nemodificirani. Provedena su tri ciklusa ispitivanja: a) uzorci su namakani $u$ vodi tijekom četiri dana, zatim su postavljeni na senzor težine da se osuše do konstantne mase; b) kratkoročno upijanje vode određeno je tenziometrom $i$ c) interakcije drva $i$ vode provjeravane su stalnim gravimetrijskim mjerenjem sadržaja vode pri izlaganju uvjetima na otvorenome. Kao što se očekivalo, stupanj modifikacije ogleda se u sadržaju vode u drvu tijekom ispitivanja. Kratkoročno i srednjoročno upijanje vode dobro korelira s ponašanjem drva u vanjskim uvjetima. Nasuprot tome, dugoročna mjerenja tenziometrom nisu bila u skladu s kratkoročnim vezanjem vode ili s mjerenjem pri izlaganju uvjetima na otvorenome.

Ključne riječi: senzor težine, Picea abies, tenziometar, toplinska modifikacija, upijanje vode, terenska ispitivanja

\footnotetext{
${ }^{1}$ Authors are PhD student, assistant and professor at University of Ljubljana, Biotechnical Faculty, Department of Wood Science and Technology, Ljubljana, Slovenia.

${ }^{1}$ Autori su doktorandica, asistent i profesor Odjela za znanost o drvu i drvnu tehnologiju, Biotehnički fakultet, Sveučilište u Ljubljani, Ljubljana, Slovenija.
} 


\section{INTRODUCTION}

\section{UVOD}

Thermal modification is one of the most commercially important modification procedures (Rapp and Sailer, 2001; Esteves and Pereira, 2009; Lacić et al., 2014). The properties of the treated products depend on the temperature and duration of modification (Altgen et al., 2012). In spite the fact that this procedure has been on the market for almost two decades, the complete mechanism of improved durability has not been fully elucidated. The increased durability has been explained by the lower equilibrium moisture content, better dimensional stability and formation of new toxic compounds (Hakkou et al., 2006). In recent research, another aspect has attracted considerable attention: water exclusion efficiency. The purpose of this study was to elucidate the correlation between the degree of modification and water exclusion efficiency, as determined by different experimental procedures.

Although there is no standardised method for determining water exclusion efficiency, several techniques are available. The majority of them are based on gravimetric measurements after longer or shorter periods of exposure to water (Humar and Lesar, 2013). These methods are fairly simple to perform but time consuming and the size of the specimens is limited. However, especially when considering the time and effort, manual weighing of the samples is not the best solution for outdoor testing, particularly if working with a larger number of specimens. Furthermore, if the specimens are weighed manually once per week, the moistest periods might be overlooked, since the specimens are not usually weighed immediately after rain. In order to speed up the test procedure, there are two possibilities: to determine the moisture content through measurements of electrical resistance (Brischke et al., 2013) or to apply single load cells for automated measurements (Van den Bulcke and Van Acker, 2008). The second method is more correlated to laboratory-gravimetric based measurements, and hence continuous monitoring of weight on single load cells was also applied in the present research.

\section{MATERIAL AND METHODS}

\section{MATERIJAL I METODE}

Samples made of Norway spruce (Picea abies) were heat treated according to the Silvapro ${ }^{\circledR}$ commercial procedure (Rep et al., 2012). Two types of sample were used: large ones $(2.5 \times 5.0 \times 50.0 \mathrm{~cm})$ and small ones $(1.5 \times 2.5 \times 5.0 \mathrm{~cm})$. Samples were thermally modified at six temperatures, as shown in Table 1. The time of modification at the target temperature for all specimens was 3 hours. The mass loss of the samples after modification was determined gravimetrically. After modification, samples were stored in laboratory for 4 weeks (24 ${ }^{\circ} \mathrm{C} ; 65 \%$ ). The conditioned samples were then subjected to various short and long term water uptake analyses.

Short term water uptake was determined on small specimens. The measurements were carried out at room temperature $\left(20^{\circ} \mathrm{C}\right)$, at $\mathrm{RH}$ of $50 \pm 5 \%$ on a Krüss Processor Tensiometer K100MK2. The specimens were positioned in the device in such a way that the axial surfaces of the specimens were in contact with the test liquid (water) and their masses were subsequently measured at 2-s intervals for $200 \mathrm{~s}$. Other parameters used were: velocity before contact $6 \mathrm{~mm} / \mathrm{min}$, sensitivity of contact $0.005 \mathrm{~g}$ and depth of immersion $0.5 \mathrm{~mm}$.

The medium term water uptake test was based on the ENV 1250-2 (1994) leaching procedure. Smaller specimens were used for this test. The water uptake study was completed in four days. Modified samples were placed in the vessel and positioned with weights to prevent them from floating. One hundred grams of distilled water were added per specimen. The water was replaced six times in four subsequent days, as prescribed by the standard (the cumulative periods of leaching were: 1 h, 3 h, 7 h, 23 h, 31 h, 47 h, 95 h). The mass of the samples was determined after each period and the moisture content of the samples was calculated.

Long term water uptake was determined on larger samples. Similarly as reported for short term water uptake measurements, samples were positioned so as to be in contact with the water and their masses were subsequently measured at 20-s intervals for the following 160 h. Samples were placed on single point load cells (HBM precix 6), with a maximum capacity of $7 \mathrm{~kg}$. Data was acquired with the PMX data acquisition system and recorded and analysed with Catman Easy software.

There are two important processes during weathering, drying and wetting. Short, medium and long term leaching procedures were designed to simulate wetting events. In this laboratory experiment, the focus was on the drying phase. The larger samples were, therefore, immersed in distilled water for 4 days. They were then mounted on HBM precix single point load cells and their mass was continuously recorded through the drying process (sampling rate $=0.02 \mathrm{~Hz}$ ).

In the last experiment, the actual moisture content of the samples was continuously monitored during outdoor exposure (sampling rate $=0.02 \mathrm{~Hz}$ ). The test set up was located in the field test site of the University of Ljubljana (latitude: $+46.0489^{\circ}$; longitude: +14.4787 ). Samples were placed in a horizontal position on single point load cells and their masses were continuously monitored, as described previously. Samples were exposed in the period Nov. 30, 2013 to March 6, 2014 for 105 days.

\section{RESULTS AND DISCUSSION} 3. REZULTATI I RASPRAVA

Thermal modification resulted in changes in the overall properties of the Norway spruce wood. Mass loss is one of the most reliable indicators of the effectiveness of thermal modification (Hill, 2006; Altgen et al., 2013). The mass loss of the specimens increased with the modification temperature as shown in Table 1. The obtained data are in line with the literature data (Esteves and Pereira, 2009; Rep et al., 2012).

The short term water uptake test is a fast and efficient method for quick estimation of hydrophobicity. 
Table 1 Influence of modification temperature on mass loss after thermal modification and short term water uptake (STWU); different letters represent different homogeneous groups within the same exposure

Tablica 1. Utjecaj temperature modifikacije na gubitak mase nakon toplinske modifikacije i kratkoročnog upijanja vode (STWU); različita slova predočuju različite homogene skupine unutar iste izloženosti

\begin{tabular}{|c|c|c|}
\hline $\begin{array}{c}\text { Modification } \\
\text { temperature, }{ }^{\circ} \mathrm{C} \\
\text { Temperatura } \\
\text { modifikacije, }{ }^{\circ} \mathrm{C}\end{array}$ & $\begin{array}{c}\text { Mass loss, } \% \\
\text { Gubitak mase, \% }\end{array}$ & $\begin{array}{c}\text { STWU, } \mathbf{g} / \mathbf{m m}^{2} \\
\text { Kratkoročno } \\
\text { upijanje vode, } \\
\mathrm{g} / \mathrm{mm}^{2}\end{array}$ \\
\hline 0 & 0.0 (a) & 0.00169 (b) \\
\hline 160 & 1.9 (b) & 0.00218 (a) \\
\hline 180 & $2.3(\mathrm{~b})$ & $0.00120(b)$ \\
\hline 190 & $3.2(\mathrm{c})$ & $0.00068(\mathrm{c})$ \\
\hline 200 & $4.4(d)$ & 0.00073 (c) \\
\hline 210 & $6.0(\mathrm{e})$ & 0.00081 (c) \\
\hline 230 & $11.7(\mathrm{f})$ & $0.00150(b)$ \\
\hline
\end{tabular}

The limitation of this test is that tests are performed on axial surfaces only. The ratio of axial surfaces in the specimens compared to real case applications is fairly small. However, axial surfaces often represent the weakest point of wooden objects in above ground applications. Unmodified spruce wood samples retained approximately $0.00169 \mathrm{~g} / \mathrm{mm}^{2}$ of water in 200 seconds. The modification of spruce at low temperature (160 $\left.{ }^{\circ} \mathrm{C}\right)$ resulted in higher water uptake $\left(0.00218 \mathrm{~g} / \mathrm{mm}^{2}\right)$. The reason for the increased water uptake is linked to certain anatomical changes, such as the destruction of tracheid walls, ray tissues, pit de-aspiration due to heat treatment and thus an increase in the wood cell wall porosity (Awoyemi and Jones, 2011). In contrast, higher temperatures of modification resulted in lower short term water uptakes. Heat treatment of wood slightly increases the free energy of wood (Kutnar et al., 2012). Furthermore, the contact angles for water in contact with wood modified at different temperatures showed greater variation but without a clear trend; only spruce treated above $210{ }^{\circ} \mathrm{C}$ exhibited a considerably higher value $\left(96,6^{\circ}\right)$ than non-modified wood (Kutnar et al. 2012). However, in spite of the increased hydrophobicity of the specimens treated at $230^{\circ} \mathrm{C}$, short term water uptakes again increased. We presume that the small cracks in the axial surface are the primary reason for increased water uptake. They act as capillaries and increase the short term water uptake. This should be elucidated in one of the future studies.
In the next step, we compare the values of the short term water uptake tests with the results of continuous immersion in water. The same specimens as used for the short term water uptake tests were immersed in water according to leaching protocol ENV 1250-2 (1994). The differences between the materials were most prominent after one hour of immersion (Table 2). The moisture content of the control specimens reached almost fibre saturation point $(28.5 \%)$. Similarly as reported for the short term tests, modification of the specimens at $160{ }^{\circ} \mathrm{C}$ resulted in higher moisture contents, while higher modification temperatures resulted in lower MC of modified specimens compared to the controls (Table 2). The only difference in wood moisture performance with medium term immersion compared to the short term water uptake was with specimens modified at the highest temperature. The moisture content of these samples after medium term immersion was the lowest among all of the specimens (Table 2). It seems that the cracks on the surface of the specimens have an influence on the uptake from the axial planes but not on the overall medium term uptake of water. With continuous immersion, the moisture content of the specimens began to increase. The influence of the modification was still evident even after 47 $\mathrm{h}$ of immersion and was similar to that already described. However, after $95 \mathrm{~h}$ of immersion, all specimens had similar MC, with the exception of the samples treated at $160^{\circ} \mathrm{C}$. The $\mathrm{MC}$ of these specimens was approximately 15 percentage points higher than the MC of other specimens (Table 2). Consequently, it can be concluded that thermally modified wood is not suitable for use in applications with permanent moisture load, like in ground contact.

In order to obtain more representative data, experiments were also repeated with larger specimens in the laboratory. Since EN 252 sized specimens $(2.5 \times$ $5.0 \times 50 \mathrm{~cm})$ performed well in past moisture related studies (Humar in Lesar, 2013), this size of specimen was chosen for the second part of the research. Firstly, we tried to simulate the tensiometer measurements with larger samples that were in contact for a longer period. The axial planes of the samples were thus positioned in contact with the water and the mass of the samples was monitored for 160 hours. Water uptake continuously increased during the overall testing period. However, visual inspections of the specimens clearly showed that the properties of not only the axial planes but other surfaces contribute to the water up-

Table 2 Moisture content of Norway spruce samples heat treated at different temperatures, after continuous immersion in water Tablica 2. Sadržaj vode u uzorcima drva norveške smreke toplinski obrađenima pri različitim temperaturama, nakon kontinuiranog namakanja u vodi

\begin{tabular}{|c|c|c|c|c|c|c|c|}
\hline Modification temperature, ${ }^{\circ} \mathrm{C}$ & \multicolumn{7}{|c|}{ Moisture content, \% / Sadržaj vode, \% } \\
\cline { 2 - 8 } Temperatura modifikacije, ${ }^{\circ} \mathrm{C}$ & $1 \mathrm{~h}$ & $3 \mathrm{~h}$ & $7 \mathrm{~h}$ & $23 \mathrm{~h}$ & $31 \mathrm{~h}$ & $47 \mathrm{~h}$ & $95 \mathrm{~h}$ \\
\hline 0 & 28.5 & 41.4 & 50.6 & 62.5 & 64.4 & 69.3 & 72.6 \\
\hline 160 & 38.9 & 51.2 & 71.5 & 79.8 & 80.7 & 85.7 & 87.8 \\
\hline 180 & 19.5 & 34.5 & 41.5 & 55.8 & 59.0 & 65.5 & 72.1 \\
\hline 190 & 15.0 & 28.1 & 38.1 & 51.9 & 55.5 & 62.7 & 70.4 \\
\hline 210 & 13.6 & 28.0 & 35.6 & 48.7 & 51.8 & 59.3 & 67.6 \\
\hline 230 & 12.7 & 25.4 & 34.6 & 48.4 & 52.4 & 60.5 & 71.0 \\
\hline
\end{tabular}




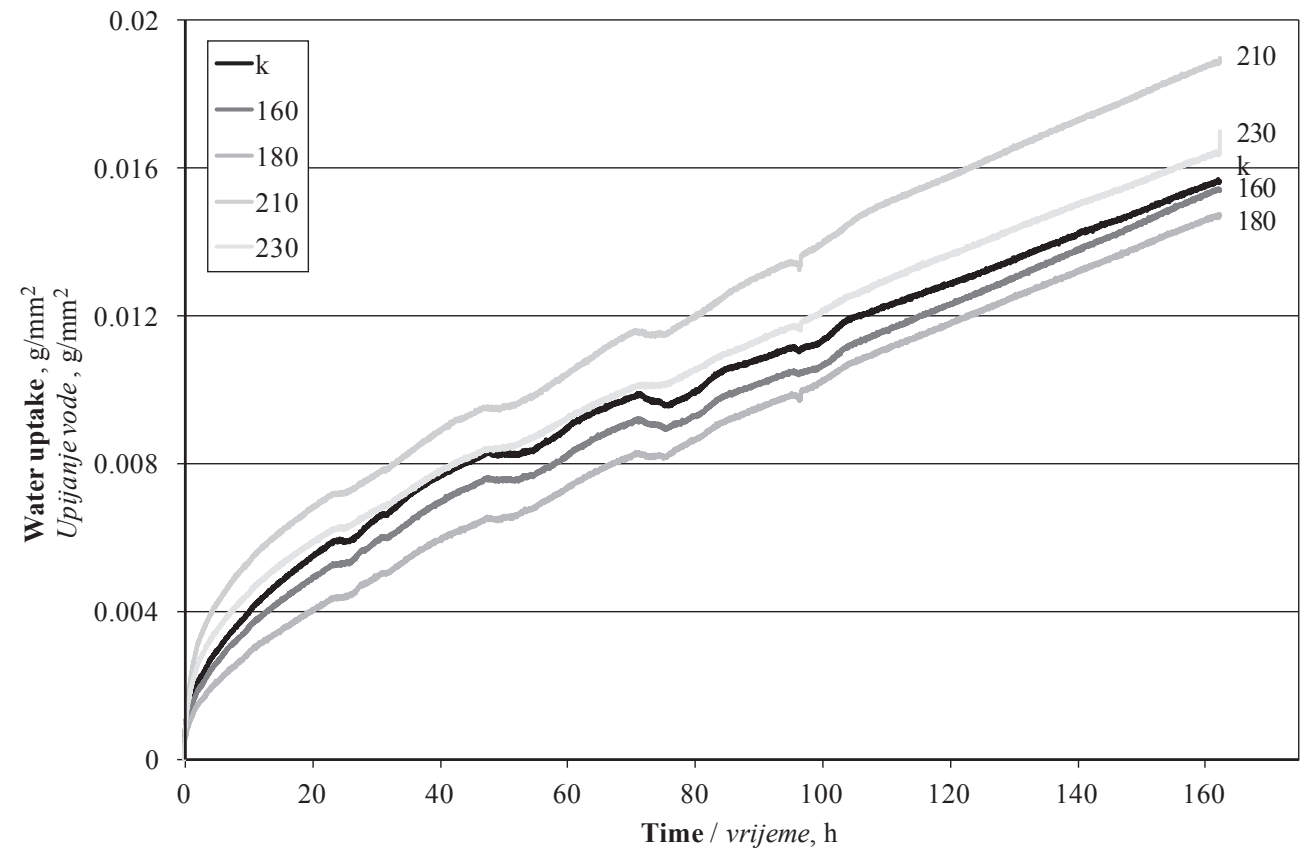

Figure 1 Water uptake from axial surfaces of EN 252 sized samples in contact with water

Slika 1. Upijanje vode aksijalne površine uzoraka drva izrađenih prema EN 252 u dodiru s vodom

take. Water was also rising through the longitudinal planes, which was evident from the dark colour of the wet wood. The results presented in Figure 1 show that the specimens modified at lower temperatures $\left(160{ }^{\circ} \mathrm{C}\right.$ and $180^{\circ} \mathrm{C}$ ) took up less water than the control specimens, while the specimens modified at higher temperatures $\left(210^{\circ} \mathrm{C}\right.$ and $\left.230^{\circ} \mathrm{C}\right)$ took up more water than the control specimens. Not all the reasons for this phenomenon can be elucidated but it is suspected that the prime reason for this is formation of the small cracks in the surface of the specimens modified at higher temperatures, which act as capillaries and increase the water uptake into the specimens.
In addition to water uptake, drying is another important phenomenon that influences the moisture content of wood during outdoor exposure. In order to elucidate this phenomenon, samples were first immersed in water for 4 days and then positioned on single point load cells in order to monitor their mass during drying. As shown in Figure 2, the initial moisture content reflects the modification temperature. Although all specimens were immersed for 4 days, the starting moisture content varied between $25.6 \%$ (control) and $16.9 \%$ (modification at $210^{\circ} \mathrm{C}$ ). This is in line with the immersion studies performed on the smaller specimens. Wood modified at higher temperatures took up less wa-

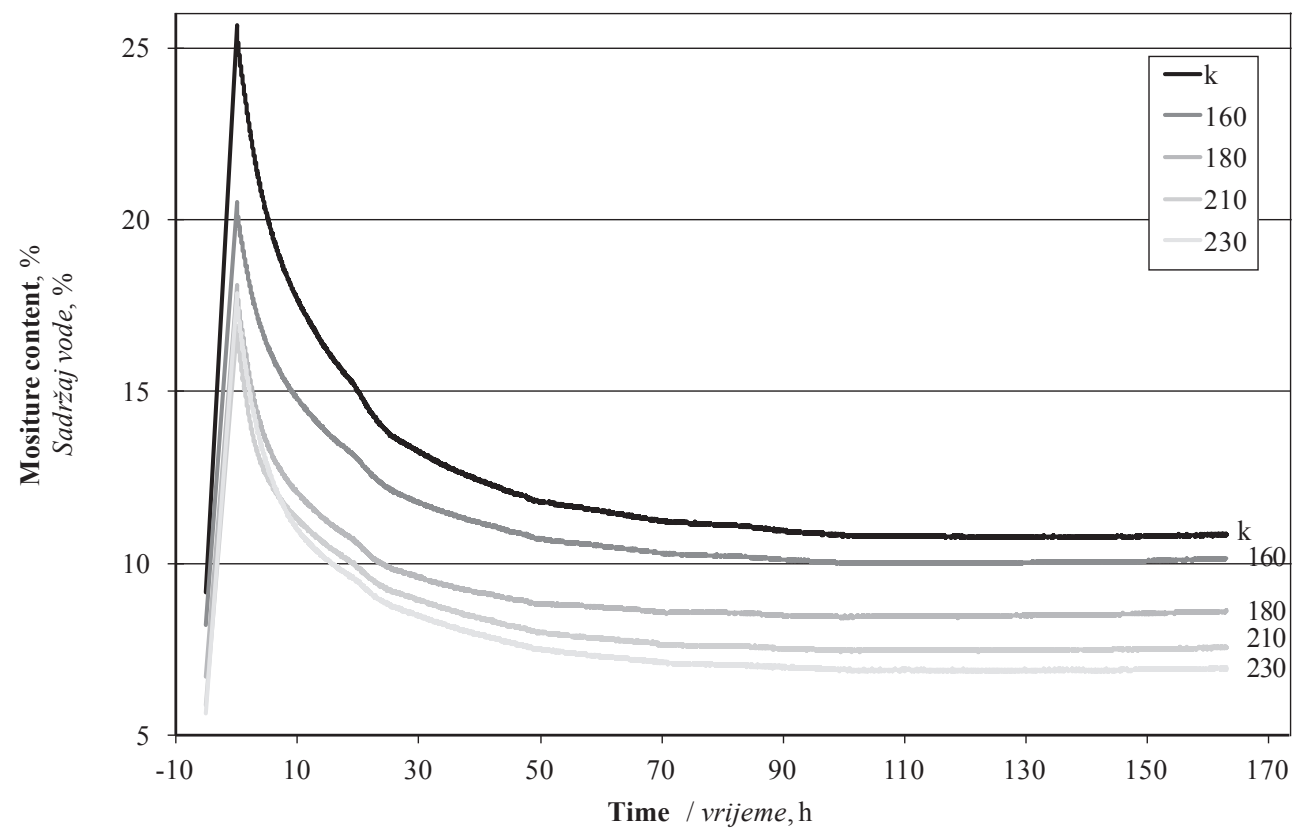

Figure 2 Drying of thermally modified specimens in indoor conditions; specimens were mounted on load cells Slika 2. Sušenje uzoraka toplinski modificiranog drva u uvjetima zatvorenog prostora; uzorci su bili postavljeni na senzore težine 


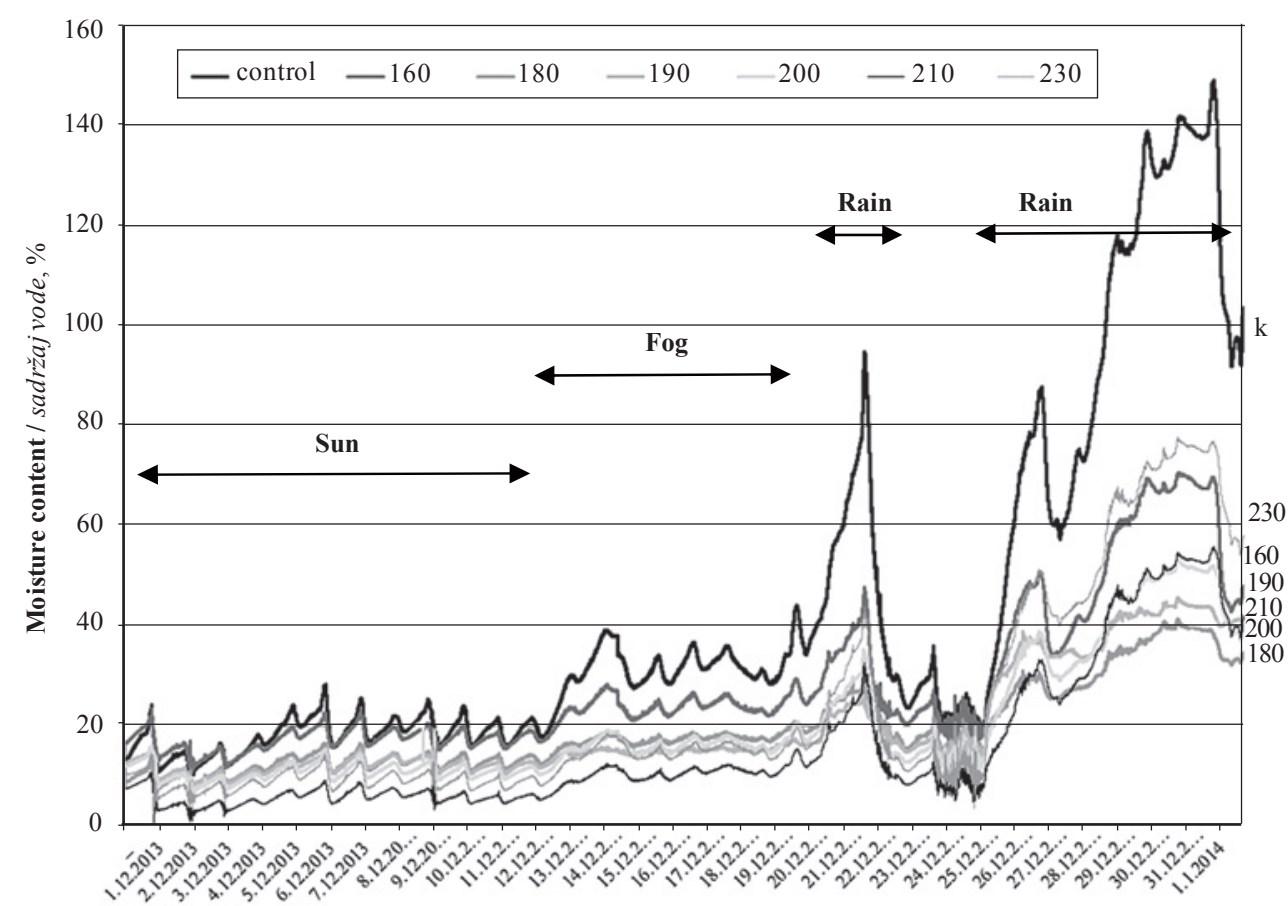

Figure 3 Influence of modification temperature on moisture content of thermally modified Norway spruce during the first month of outdoor exposure

Slika 3. Utjecaj temperature modifikacije na sadržaj vode toplinski modificiranog drva norveške smreke tijekom prvog mjeseca izlaganja na otvorenome

ter than wood modified at lower temperatures and control (unmodified) wood. The final MC at the end of the drying process clearly correlated with the temperature of the modification. A higher modification temperature resulted in a lower $\mathrm{MC}$ at the end of the drying period. Regardless of the modification temperature, the final $\mathrm{MC}$ was determined after $100 \mathrm{~h}$ of drying.

In the last part of the experiment, moisture monitoring was performed during outdoor exposure. During the first ten days of exposure, there was no rainfall. This was clearly reflected in the MC of the samples (Figure 3). The average $\mathrm{MC}$ of the samples varied between $6 \%$ $\left(210{ }^{\circ} \mathrm{C}\right)$ and $18 \%$ (control). With the exception of the highest modification temperature, a higher modification temperature resulted in a lower $\mathrm{MC}$ during the initial days of exposure. This was expected, since in the absence of rainfall, only sorption and desorption influence the MC of the exposed samples. Similar relations were determined during a foggy period, with the only significant difference being that the average $\mathrm{MC}$ was considerably higher: $17 \%$ for specimens modified at $210{ }^{\circ} \mathrm{C}$ and $33 \%$ for control specimens. However, during a rainy period, MC relationships changed considerably. The highest average value was again determined on control specimens, while specimens modified at $180^{\circ} \mathrm{C}$ and 190 ${ }^{\circ} \mathrm{C}$ had the lowest average MC. This result indicates that not only the sorption properties but other physical properties of the modified wood reflect its performance during outdoor exposure, predominantly during and after extensive rain. Moisture performance is a function of the sorption properties, surface properties and permeability and thus cannot be assessed with a single laboratory test (Figure 3). Furthermore, it should be considered that different mechanisms are responsible for capillary water uptake and sorption.
Comparison of the daily rainfall and moisture content revealed that intensive rain events considerably influence the moisture content (Figure 4). There were 31 days with a moisture content of the control specimens above $100 \%$. There are two reasons for such a high moisture content. Firstly, in total there were $520 \mathrm{~mm}$ of rain during the 100 days of exposure, in 53 rain events, of which 17 days were snow that was deposited on the specimens and afterwards slowly melted and wet the specimens more effectively than rain. Further information shown in Figures 3 and 4 concerns the velocity of drying. Although the specimens were very wet, they dried very fast. For example, the moisture content of control specimens was reduced from $100 \%$ to $20 \%$ in two to three days (Figure 4). However, it should be born in mind that the constructions contained no water trap and the specimens were positioned on two fasteners only, which allowed good circulation of air and thus resulted in fast drying. This drying was significantly faster than drying of green timber.

However, long term data are fairly difficult to analyse and compare. Data presented in Figure 4 are, therefore, summarised in Table 3. It is evident from these results that control specimens had the highest average MC (69\%) and specimens treated with $210{ }^{\circ} \mathrm{C}$ $(35 \%)$ the lowest. These results are in line with laboratory data obtained in this study (Table 1 and 2). Similar relationships were determined with other statistical aggregates. However, from an application point of view, the days with a moisture content above $25 \%$ are the most important data since this is accepted to be the limit for effective fungal decay (Welzbacher et al., 2009). There are some fungi that can grow at a lower MC but decay caused by such fungi is not likely out- 


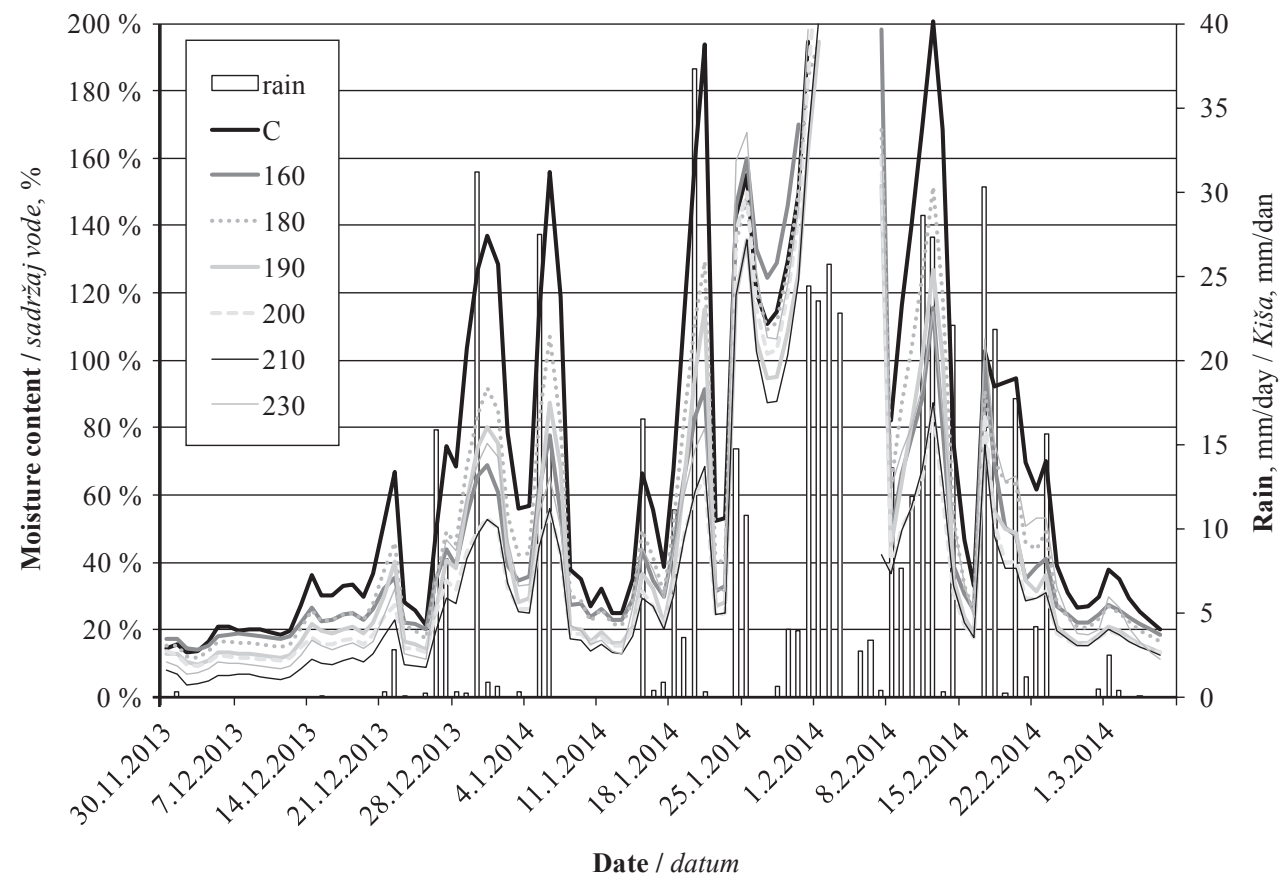

Figure 4 Influence of modification temperature on the correlation between the average daily moisture content of wood specimens and daily rainfall

Slika 4. Utjecaj temperature modifikacije na korelaciju između prosječnoga dnevnog sadržaja vode u uzorcima drva i dnevne količine oborina

Table 3 Influence of modification temperature on mean, median and maximum values of the specimens. Number of days above $20 \%, 25 \%$ and $30 \%$ wood moisture content (MC) during 105 days of natural weathering; MC was determined gravimetrically and recorded once per minute. Days when specimens were under snow were not considered as maximum values.

Tablica 3. Utjecaj temperature modifikacije na srednje vrijednosti, medijan i maksimalne vrijednosti sadržaja vode u uzorcima; broj dana sa sadržajem vode (MC) u uzorcima drva većima od 20, 25 i 30 \% tijekom 105 dana izlaganja na otvorenome; sadržaj vode određen je gravimetrijski i bilježen jedanput u minuti; dani kada su uzorci bili pod snijegom nisu uzeti u obzir pri određivanju maksimalne vrijednosti sadržaja vode

\begin{tabular}{|l|c|c|c|c|c|c|c|}
\hline Moisture content, \% & \multicolumn{7}{|c|}{ Modification temperature, ${ }^{\circ} \mathrm{C} /$ Temperatura modifikacije, ${ }^{\circ}$ C } \\
\cline { 2 - 9 } Sadržaj vode, \% & control & 160 & 180 & 190 & 200 & 210 & 230 \\
\hline Mean, \% / Srednja vrijednost, \% & 69 & 52 & 55 & 45 & 40 & 35 & 48 \\
\hline Median, \% / Medijan, \% & 54 & 35 & 41 & 29 & 26 & 25 & 33 \\
\hline Max (\%) / Maksimalna vrijednost, \% & 201 & 160 & 152 & 136 & 150 & 136 & 168 \\
\hline \# days MC > 20 \% / Broj dana s MC > 20\% & 87 & 84 & 80 & 64 & 56 & 53 & 64 \\
\hline \# days MC > 25\% / Broj dana s MC > 25\% & 82 & 65 & 64 & 53 & 50 & 47 & 58 \\
\hline \# days MC > 30\% / Broj dana s MC > 30\% & 70 & 54 & 55 & 47 & 43 & 40 & 54 \\
\hline
\end{tabular}

doors. During the exposure period of 105 days, the MC of the control specimens was higher than $25 \%$ on 82 days. On the other hand, there were only 47 days on which the $\mathrm{MC}$ of the specimens modified at $210{ }^{\circ} \mathrm{C}$ was above $25 \%$. This indicates sufficient moisture performance of modified wood if not in permanent contact with liquid water. The reasons for this have already been discussed and can be summarised as a lower hemicellulose content, fewer $\mathrm{OH}$ groups and lower surface energy.

\section{CONCLUSIONS}

\section{ZAKLJUČAK}

Thermal modification of wood considerably improves its performance against wetting. The highest level of correlation between laboratory and outdoor testing was determined between short term tests and outdoor moisture monitoring on single point load cells. However, it is evident from the presented results that a single laboratory procedure is not enough for prediction of the moisture performance outdoors. In order to determine a comprehensive moisture performance, multiple techniques have to be applied.

\section{Acknowledgements - Zahvala}

The authors would like to acknowledge the support of the Slovenian Research Agency in the framework of programme P4-0015 and project L4-5517.

\section{REFERENCES}

\section{LITERATURA}

1. Altgen, M.; Welzbacher, C.; Humar, M.; Willems, W.; Militz, H., 2012: Bestimmung der Behandlungsqualität von Thermoholz mithilfe von Schnellverfahren. Holztechnologie, 53 (6): 44-49. [in German language]. 
2. Awoyemi, L.; Jones, I. P., 2011: Anatomical explanations for the changes in properties of western red cedar (Thuja plicata) wood during heat treatment. Wood science and technology, 45: 261-267 http://dx.doi.org/10.1007/ s00226-010-0315-9.

3. Brischke, C.; Meyer, L.; Bornemann, T., 2013: The potential of moisture content measurements for testing the durability of timber products. Wood science and technology, 47 (4): 869-886 http://dx.doi.org/10.1007/s00226013-0548-5.

4. ENV 1250-2, 1994: Wood preservatives - Methods for measuring losses of active ingredients and other preservative ingredients from treated timber - Part 2: Laboratory method for obtaining samples for analysis to measure losses by leaching into water or synthetic sea water. European Committee for Standardization, Brussels.

5. Esteves, B. M.; Pereira, H. M., 2009: Wood modification by heat treatment: A review. Bioresources, 4 (1): 370-404.

6. Hakkou, M.; Pétrissans, M.; Gérardin, P.; Zoulalian, A., 2006: Investigations of the reasons for fungal durability of heat-treated beech wood. Polymer degradation and stability, $91 \quad$ (2): 393-397 10.1016/j.polymdegradstab.2004.04.042.

7. Hill, C., 2006: Wood Modification-Chemical, Thermal and Other Processes. Wiley, UK, pp. 260 http://dx.doi. org/10.1002/0470021748.

8. Humar, M.; Lesar, B., 2013: Efficacy of linseed- and tung-oil-treated wood against wood-decay fungi and water uptake. International biodeterioration and biodegradation, 85: 223-227 http://dx.doi.org/10.1016/j.ibiod.2013.07.011.

9. Kutnar, A.; Kričej, B.; Pavlič, M.; Petrič, M., 2013: Influence of treatment temperature on wettability of Norway spruce thermally modified in vacuum. Journal of adhesion science and technology, 27 (9): 963-972 http://dx. doi.org/10.1080/01694243.2012.727168.
10. Lacić, R.; Hasan, M.; Trajković, J.; Šefc, B.; Šafran, B.; Despot, R., 2014: Biological durability of oil heat treated alder wood. Drvna industrija, 65 (2): 143-150 http://dx. doi.org/10.5552/drind.2014.1256.

11. Rapp, A. O.; Sailer, M., 2001: Oil-heat-treatment of wood - process and properties. Drvna industrija, 52 (2): 63-70.

12. Rep, G.; Pohleven, F.; Košmerl, S., 2012: Development of the industrial kiln for thermal wood modification by a procedure with an initial vacuum and commercialisation of modified Silvapro wood. In: The sixth European conference on wood modification. Jones, D. (ed.); Militz, H. (ed.); Petrič, M. (ed.); Pohleven, F. (ed.); Humar, M. (ed.); Pavlič, M. (ed.); University of Ljubljana, Biotechnical Faculty, Department of Wood Science and Technology, Ljubljana, Slovenia, pp. 11-17.

13. Van den Bulcke, J.; Van Acker, J., 2008: Time resolved analysis of the moisture dynamics of plywood. Cost Action E37 Final Conference in Bordeaux, Socio-economic perspectives of treated wood for the common European market. pp. 65-75.

14. Welzbacher, C. R.; Brischke, C.; Rapp, A. O.; Koch, S.; Hofer, S., 2009: Performance of thermally modified timber (TMT) in outdoor application - durability, abrasion and optical appearance. Drvna industrija, 60 (2): 75-82.

\section{Corresponding address:}

Prof. MIHA HUMAR, Ph.D.

University of Ljubljana, Biotechnical Faculty Department of Wood Science and Technology Jamnikarjeva 101 SI-1000 Ljubljana, SLOVENIA e-mail: miha.humar@bf.uni-lj.si 